\title{
Creativity and Innovation in the Context of Team-work: an Evaluation in the Self-management Cells and Quality Control Circles of Ambev S.C. Branch
}

\author{
Felipe de Faria Monaco* \\ E-mail address: felipemonaco@hotmail.com \\ Universidade Federal de Santa Catarina \\ Florianópolis, SC, Brazil \\ Valeska Nahas Guimarães \\ E-mail address: valeska_kenaz@yahoo.com.br \\ Universidade Federal de Santa Catarina \\ Florianópolis, SC, Brazil
}

\begin{abstract}
This paper is about changes in the business world. The main goal is to study the implications related to people's creativity expression owing to work organization in small groups in the Ambev S.C. branch. This is a qualitative study based on a case study. 21 self-management circles and 18 quality control circles in the organization were found. The self management circles are responsible for achieving the organizational main goals and the quality control circles to bring best practices and new ideas. The result shows that quality control circles are more powerful than the self management circles as a space to develop people creativity and organizational innovation. It is relevant to stress that in the CCQs there are more multidisciplinary and common purpose guided to a collective objective desired by all the members of the team. On the other hand, in the CGA's there are more discipline to accept the common tactics to people reach the objectives of the group and the corporative aims. The conclusion is that the changes in the business environment make the small work group very important to a company's creativity and a fundamental strategy differentiation in the process of work organization in the context of the business world.
\end{abstract}

Key words: creativity and innovation; team work; organizational changes; self-management cells; quality control circles.

Received 02 November 2005; received in revised form 30 June 2006.

Copyright (C) 2007 Brazilian Administration Review. All rights reserved, including rights for translation. Parts of this work may be quoted without prior knowledge on the condition that the source is identified.

* Corresponding author: Felipe de Faria Monaco

Universidade Federal de Santa Catarina, Centro Sócio-Econômico, Campus Universitário Trindade, Florianópolis/SC, 88040-900, Brazil. 


\section{INTRODUCTION}

In recent decades, the world has witnessed great changes in the economic, social, political, cultural and ethic relations. The changes occurred in the environment as we are in a period in which transformations take place at an accelerated pace and integrate the daily routine of almost all of the sectors of society (Galbraith \& Lawler, 1995). The information technologies, the commerce globalization, the formation of economic groups and the international crisis have imposed new conditions on institutions, reconstructing the working world and causing great impacts in the organizational field.

One of the greatest challenges in the context of economic and productive restructuring is finding the balance between the introduction of innovations in work administration and the adaptation of people to the new technologies. Among this, in a period of extreme instability and crisis, many companies have been trying to adjust their administrative models to the new reality, without worrying about the cultural adjustment aspects to the new technologies, not even with the democratic introduction and negotiation among the diverse performers involved.

One alternative that has been more and more used is the introduction of work in autonomous and improvement groups, as these groups become particularly important to the companies in a context in which the changes are frequent and the evolution process is fast. Despite the advantages, such as the motivational factor of workers, the capacity of innovation and the possibility of providing fast answers to the resolution of problems; team-work can be inefficient as a change agent and innovation in the institutions, in case it faces cultural obstacles and structural power.

In light of the problem, Neves (1998) voices some doubts that are also relevant to this work: How far do the new participative policy, the team-work, the stimulus to autonomy and creativity make the work relations democratic, replacing the authoritarianism and control of the Taylor-Ford model? Besides this, how far does teamwork become essential to creating flexibility and innovation in institutions? Are the teams organized with the intention of developing creativity expressiveness at work? Are the teams used as a management strategy to control the work process through the relative autonomy granted to the worker or do they really constitute agents of organizational changes?

In light of these speculations, which lead to a constantly growing of complexity in the working world, the present study intends to deepen the discussion about the creativity expressiveness of people in the context of small team working.

Because of this, the main methodological propositions are posed followed by the theory and the interpretation of data, and conclude with final considerations.

\section{RESEARCH METHODOLOGY}

The research began through an exploratory study; then it took on a descriptive outline. The exploratory outline served to enlarge knowledge of the theoretical questions on the theme, and the selection of the company to carry out the study.

In the exploratory stage, at an organizational level, the acknowledgement of the general situation of the institution was accomplished and specific documents were obtained. Then, there was a comprehension of necessary elements to the conduction of the descriptive step as well as the collection of data on the staff, the structuring and organization of work in self-management cells (CGA - Célula de Gestão Autônoma) and in quality control circles (CCQ - Círculo de Controle da Qualidade). 
The study also contains a descriptive outline, in which the opinion of people concerning the functioning and characterization of groups was investigated, as well as the creativity expressiveness in the organized work in CGA and CCQ.

The approach of the study is mainly qualitative while the selection and choice of the methodological procedure fall back on the case study. This choice was made due to the consideration that this has been distinguished as one of the most adequated procedures to the qualitative approach (Richardson, 1999; Trivinos, 1987). The case study also permits an efficient analysis of complex situations, without missing the richness of relations and interactions of its components. Furthermore, it is a procedure that allows the collecting, detailing and intensive analyzing of a great deal of information from an institution facilitating the phenomenon under study (Bruyne, 1977).

The data were collected from primary and secondary sources. The survey of secondary sources was accomplished through bibliographic, documental and telematized surveys (Vergara, 1997). The collection of primary data was accomplished through interviews, documental consultation and research in electronic files. During this phase, an effort was also made to gather quantitative data concerning the general situation of the company, employees profiles and the mapping of the institution's network.

In the second phase, the primary data were collected through the application of semi-structured interviews with the members of Self Management Cells (CGA) and Quality Control Circles (CCQ) at the Ambev S.C branch. In relation to the workers, of 214 employees of the institution, 61 of them were interviewed. In the preliminary mapping, 21CGA's with 214 members were identified in operation at the Ambev - branch office/S.C. The application of interviews was done with 58 members of the 08 selected CGA's and at the same time the CCQ's were observed. In relation to the Quality Control Circles at the Ambev - branch office / SC, the preliminary mapping indicated the existence of 18 active CCQ's at the company. Of the 214 employees of the unit, 146 (68\%) were registered in some of these groups (CCQ's). From a total of 61 interviewed, 45 (75\%) were part of some CCQ group and 16 (26\%) did not participate. Of a total of 214 employees in the unit, 61 people were interviewed: the unit manager (01), the manufacturing manager (01), the People and Quality coordinator (01) and 58 CGA's members.

The elements of the sample were chosen using a qualitative criterion and they do not constitute at all a representative sample in the statistic way. The criteria for selection of the sample were: the function and the capacity of the employee, his/her education, the period he / she has been working at the company, their age and sex. In coherence with the qualitative approach (Michelat, 1987), the individuals were chosen who represented the most diverse categories, constituting therby a heterogeneous sample that represents the organizational reality.

The interviews received a qualitative treatment in their analysis. Due to this factor, a vertical and horizontal reading procedure was adopted (Michelat, 1987). To broaden the horizon of information analysis and to verify the existence of conflicting testimony among those interviewed, a technique of triangulation of data and content analysis was used (Trivinos, 1987). The triangulation of the data was used for the confrontation of the information obtained through the application of interviews with the employees, in the documents of the company and by the researcher's observation during the accomplishment of the study. The observation was systematized with the use of the field diary that was constituted as an important instrument for confrontation of the data obtained from other sources. The application of the triangulation of the data allowed the researcher to broaden the horizon of the collected information through company documents, observation and interviews with the managers, coordinators and workers. With the adoption of these procedures, it was possible to obtain a broader vision of the organization reality. 


\section{BRIEF COMMENTS ON CREATIVITY AND INNOVATION AT WORK}

At first it is important to observe that in agreement with Isaksen (1990) creativity and innovation "must be seen as a multi-faceted phenomenon rather than as a single construct to be precisely defined" (p. 169). One of the factors that contribute to the complexity of the conceptions of creativity is that it is an interdisciplinary phenomenon. However in the latest definitions of creativity we can find the Latin term creare and the Greek term krainen. This means that creativity is the discovery of new shapes, symbols, patterns, processes and ideas on which new work and society environments can be built (May, 1975).

To West and Farr (1990) innovation is "the intentional introduction and application within a role, group or organization of ideas, processes, products or procedures, new to the relevant unit of adoption, designed to significantly benefit the individual, the group, organization or wider society" (p. 09). This definition is not restricted to technological change but subsumes new ideas or processes in administration or human resource management.

In this sense, according to West and Farr (1990) work environments are often damaging to our health, well-being and effectiveness. Thus, the study of creativity and innovation at work is a very interesting subject because it brings a reflection on organization's strategies to meet the challenge of how to bring about changes in work environments. De Bono (1994) shares this vision saying that creativity and innovation at work are assuming levels of growing importance in our society, mainly in the context of organizations. Argyris (1992) believes that creativity in the context of organizations is a way to overcome defensive routines, resistance to change and innovation.

West and Farr (1990) highlight that, far form being an isolated indication of genius, creative expression in the world of work is manifested by almost everyone, since they are given the appropriate facilitating environmental conditions. Isaksen (1990) believes that it is not surprising to find some individuals who feel creativity is something mystical and, as such, too difficult to understand and analyze, especially when we approach the subject in the context of teams.

West and Farr (1990) believe that "the study of innovation presents an optimistic picture of people's involvement in their social and organizational contexts, and promises to advance our understanding of how they can be effective in transforming and shaping organizations” (p. 12). According to King and Anderson (1990) the most frequently mentioned and important aspects that should be considered for the study of the expression of creativity at work are leadership, cohesiveness, group longevity, group composition and group structure.

Goleman, Kaufman and Ray (1992) understand that creativity and innovation demand that the managerial culture encourages the freest expression and the open exhibition of ideas. Furthermore, one of the dimensions that affect creativity at work is estrangement produced by the hierarchy. The best atmosphere for creative and innovative work seems to be that in which people have the opportunity to get to know each other and work as a team.

Specifically speaking of creativity and innovation in the context of team-work, Amabile (1990) describes three major categories as obstacles and stimulants to creativity and innovation at work: (1) factors of organizational climate or corporate culture, such as attitudes towards innovation and risktaking, organizational structures, evaluation systems, communication channels, and reward procedures; (2) factors of management style, both at the level of the organization or division and at the level of the individual project; and (3) resources, including resources of materials, money, people and time.

To create a group's creativity work environment Isaksen (1990) states that it is important to pay attention to the external environment, the internal climate of the individuals within the group and the quality of the interpersonal relationships among group members. Alencar (1995) observes that the psychological climate, the existence of freedom in the work place, the organizational structure, the 
application of flexible policies with emphasis on trust and cooperation, the respect of differences and diversity, initiative and challenges, autonomy and delegation of authority and responsibility are very important factors that should be considered by the managers in order to create an open environment for people's creativity in the organizational context.

In the wake of these brief comments on creativity and innovation in teamwork, at this moment we are going to present the researched institution and to them talk about the study conducted at the Self Management Cells and the Quality Control Circles at the Ambev S.C. branch.

\section{THE RESEARCHED INSTITUTION}

Ambev (American Beverage Company) is the result of a process of fusion of former rivals (Brahma, Skol and Antarctica), becoming the first Brazilian beverage multinational and the third largest brewery in the world. Concerning the object of study, construction work began on the Ambev S.C. branch on January $2^{\text {nd }}, 1994$ in an area that occupies 45,000 $\mathrm{m}^{2}$. The branch office for Santa Catarina (FSC Filial de Santa Catarina) is a landmark in the history of the company, the former Brahma brewery, because it was the first totally automatized unit and its layout served as a model for factories built from 1994 on.

As for the characteristics of working environment, the manager of FSC observes that the Ambev culture is characterized by the 'quest for challenges. Our company really thinks of growing, let's say that the value is added to the shareholder'. One of the employees emphasized, 'The only people that enter Ambev are those who have objectives and like challenges'. The working environment is competitive and stressful and the pressure for results is great. According to the People and Quality manager 'the company has an aggressive characteristic, in that it is always seeking innovations and striving to be the most competitive in the market'. Besides that, among the characterizing aspects of the company, the meritocracy, the informality, opening to expose ideas, the quality demand and innovation at work were also observed.

Considering the initial exploratory mapping accomplished in the institution, two types of groups, which fit into the interest field of this study, were basically identified. The first type is the Autonomous Administrative Cell (CGA) and the second one is the Quality Control Circles (CCQ).

\section{The Self Management Cells at Ambev S.C. Branch}

In relation to the CGA's, the introduction of the system began with the establishment of the factory from the Total Productive Maintenance model (TPM - Manutenção Produtiva Total). The Ambev S.C. branch was chosen as one of the pilot units to the establishment of the TPM program (Total Productive Maintenance). According to Nakajima (1989), the TPM aims at zero fault and zero breakage of machines while it intends to reach indexes of zero imperfections in products and zero loss during the process. The TPM represents the ceaseless quest for optimizing the performance of an industry through the maximizing of the efficiency of machines.

Afterwards, the TPM program required revision because its objectives were not clearly defined and there was a lack of vision and credibility of the program and excessive individualization of work was noticed. At this moment, the idea of the introduction of the CGA's, which are groups of individuals who operated a limited number of equipment in the same area of performance, appears with autonomy to plan the work having in mind reaching the established goals in the corporative aims. The CGA's are part of the formal institutions and have very delimited purposes and are defined by the corporative aims. The objective of the CGA is to prepare the workers through training and guidance in order to 
qualify them for the administration of their working environment in a more autonomous way (Ambev, 2001a).

In the preliminary mapping, 21 CGA's were identified in operation between April and May of 2001 at Ambev S.C. branch. Concerning the classification of the groups, there are 09 (43\%) administrative CGA's and 12 (57\%) industrial CGA's distributed in 06 areas: People and Quality, Financial, Environment, Packing, Brewery and Allotment (Table 01). It is important to mention that some areas are subdivided into more than one work cell as the Packing CGA that is divided in 11 work cells (08 industrial and 03 administrative), the Brewery CGA that is divided in 04 cells (03 industrial and 01 administrative) and Allotment CGA that is divided in 03 work cells (03 administrative).

Table 01: Self Management Cells at Ambev S.C. Branch

\begin{tabular}{l|c|c|c|c}
\hline \multicolumn{1}{c|}{ Denomination (CGA) } & Members & Members Interviewed & Area & Kind \\
\hline Management & 06 & 02 & ---- & --- \\
\hline People and Quality & 10 & 10 & $\begin{array}{c}\text { People and } \\
\text { Quality }\end{array}$ & Administrative \\
\hline Financial & 12 & ---- & Financial & Administrative \\
\hline Environment & 09 & ---- & Environment & Industrial \\
\hline Packing & 121 & 29 & Pack & Industrial / Administrative \\
\hline Brewery & 41 & 17 & Brewery & Industrial / Administrative \\
\hline Allotment & 15 & 03 & Allotment & Administrative \\
\hline \multicolumn{1}{c|}{ Total } & $\mathbf{2 1 4}$ & $\mathbf{6 1}$ & ----- & ----- \\
\hline
\end{tabular}

Source: Primary Data, 2001.

According to Salerno (1999), when it comes to autonomy, these groups could not be considered completely autonomous as proposed in its denomination, mainly because the space to the accomplishment of objectives is limited. Nevertheless, it was verified that in relation to the general administration and production organization the workers have autonomy to administration and production organization. The workers have the autonomy to administer their own budget, influence operational planning, and establish the division of work and maintenance of equipment. Concerning the human resource administration, the cell has autonomy to plan the hour bank and the training schedule, participate in the selection of new members and evaluate the teams and their members.

In the CGA's there are not predetermined fixed tasks for each employee, and their supervision has the function of linking the groups to the external environment. It can be verified that the definition of function and division of work is done in a participative way, taking into consideration the affinity to the determination of activities, but in a general way, when the members of the group do not come to a consensus, the hierarchical authority does the distribution of work. Yet, confirming Ruas, Antunes and Roese (1993) we should register that the expression "consensus" (agreement) means the acceptance of the workers that the accomplishment of some activities of the company can be also a result in some counterparts, just as job stability, higher wages, indirect benefits, higher professional valorization within the company and better working conditions.

The cooperation among workmates is very evident in the unit, but atmosphere of much competition between the CGA's was also seen, emphasizing that among different units the dispute for the Manufacturing Excellency Program (PEF - Programa de Excelência Fabril) is harder still. However, it is emphasized that there is sympathy and reciprocal support between workers when necessary, mainly in the quest for results and productiveness in the groups.

Generally, problems are solved through the use of quality tools and the autonomy for decision making together with the concept of the business owner, making motivation, involvement and participation of the workers with the organizational aims to be obtained in a very subtle way. In this way, it was seen that autonomy means reaching the aims set by the corporative and managing the 
supposed mini-factory formed by the CGA. For that, the workers have relative autonomy to organize the work and execute tasks, administer the resources and maintenance of the equipment, but always aim for objectives and goals.

It is considered that the CGA's present characteristics that approximate them to the semiautonomous groups diffused in the Socio - Technical approach. In the 50's, the Socio-Technical Approach (AST - Abordagem Sócio-Técnica) suggested that through harmonizing organizational interests and individual interests, it would be possible to reduce antagonism, which goes along with the relation between capital and work. In the AST an attempt is made to value the human being as a professional and as a person capable of exposing his / her ideas and participate in decision making, without forgetting to consider the relevance of optimizing the technical sub-system. Regarding teamwork, the AST becomes important, since one of its characteristics is the whole optimization principle, emphasizing the interrelation among the social and technical sub-systems, as well as the relations between the environment and the institution as a whole. In the context of teamwork, which is relevant to this article, we also call attention to the fact that the people control their own activities and keep a certain degree of autonomy to accomplish their tasks (Garcia, 1980; Guimarães, 1994).

In this sense, it was observed that many employees are conscious of the scope of the autonomy at work, as well as the limits of the acting within the company, bearing in mind that the autonomy of workers is increasingly associated to what to do and to how to do it (methods) than to why to do it. Because of this, it is confirmed that the relative ease in the command of work (means) corresponds to a prescription of the objectives and aims (result) that the groups should achieve (Salerno, 1999).

\section{The Quality Control Circles at Ambev S.C. Branch}

Another very used way of organizing the teamwork in current context is the one from the toyotist model of production, characterized by the improvement group. In this work, the Quality Control Circles (CCQ) are approached, which constitute into an implemented technique in Japan in the beginning of the 1960's by the necessity of improving the image of quality of Japanese products.

In this case, the CCQ's were implemented and are compound by small groups of employees who strive to improve their working conditions and environment. These groups are formed with the aim of finding solutions for organizational problems, improving the working environment and the evaluation of the morale of the employees through their participation in the process of generating ideas. Even though they play an important role in the process of organizational improvement, they often constitute only one form of manipulative involvement of employees instead of constituting a true instrument of democratizing the working relations (Guimarães, 1995; Leite, 1994; Ruas \& Antunes, 1997).

The process of establishing the CCQ program called Making It Happen at Ambev started in 1997 through the pilot units (branch office / SC and Agudos / SP). With the development of some training, on November $29^{\text {th }}$ of 1997 the first CCQ was formed in the S.C. branch.

The CCQ's are informal groups in which only those people that have a volunteer interest in participating take part on it. These groups are formed by a small number of people that seek developing activities with the objective of improving the working environment and the organizational practice (Ambev, 2001b).

As shown in Table 02 the preliminary mapping indicated the existence of 18 active CCQ's in the company from April to May of 2001. From the 214 employees of the unit, 146 (68\%) were registered in some of these groups. From a total of 61 interviewed, 45 (75\%) were part of a CCQ group and 16 (26\%) did not participate. 
The objective of the interviews with individuals that did not participate in the CCQ Program was to have a different view in relation to the perception of the ones that are out of the boundaries of the groups. It is important to call the attention to the fact that of the 146 employees registered in a CCQ group 45 people were interviewed. With this, a representativeness of approximately 31\% was obtained taking into account the total of employees that participate in the Quality Control Circles in the company researched.

Table 02: The Quality Control Circles at Ambev S.C. Branch

\begin{tabular}{l|c|c|c}
\hline \multicolumn{1}{c|}{ Denomination } & Creation Date & Members & Members Interviewed \\
\hline Neurônios à 1000 & $07 / 01 / 1998$ & 07 & 03 \\
\hline SOS Qualidade & $19 / 12 / 1997$ & 05 & 02 \\
\hline Os Caçadores & $31 / 01 / 1998$ & 10 & --- \\
\hline CCQ BZ - Hightech & $01 / 02 / 2001$ & 10 & 08 \\
\hline Brassagem & $09 / 02 / 2001$ & 08 & 02 \\
\hline Garra & $16 / 12 / 1998$ & 08 & 01 \\
\hline Bio-Group & $23 / 01 / 1998$ & 06 & 03 \\
\hline Powertech & $20 / 01 / 1999$ & 07 & 10 \\
\hline Os Corujas & $06 / 07 / 1998$ & 10 & ---- \\
\hline Cerveja como te quero & $18 / 12 / 1998$ & 09 & 01 \\
\hline Águia & $09 / 09 / 1999$ & 06 & 02 \\
\hline Visão & $25 / 03 / 1999$ & 10 & 01 \\
\hline Tornado & $01 / 04 / 1999$ & 07 & 02 \\
\hline Energia & $01 / 04 / 1999$ & 10 & 06 \\
\hline Os Adegueiros & $30 / 01 / 2001$ & 11 & 01 \\
\hline Milênio - Alpha & $23 / 02 / 2001$ & 08 & 01 \\
\hline Mega Watts & $09 / 03 / 2000$ & 06 & $\mathbf{4 5}$ \\
\hline Zik Zira & $20 / 06 / 2000$ & $\mathbf{1 4 6}$ & \\
\hline \multicolumn{1}{c|}{ Total } & ---- & & 02 \\
\hline Source: Primary Data 2001 & & &
\end{tabular}

Source: Primary Data, 2001.

During the study it was possible to observe the weakening of the Making It Happen Program (CCQ) and trying to promote the CCQ's, the company have been using some strategies, among them, the uniting of CGA's and CCQ's in some pilot areas. In general, it was observed that this has been causing confusion as to the objectives and limits of each program, for both the employees and the management. In a way, this strategy inhibits the volunteer character of CCQ and the groups lose in diversity, because the meeting of the groups starts to happen with the same people at the same time, and, it is perceived that the unifying of programs is a dangerous strategy because they differ in philosophy, mission and objectives. That is why it is believed that the company needs to clearly define what it intends with each program, and in this way, it limits the area of performance of each group. For that reason it is believed that the recovery of the CCQ program should have been done by the remodeling of the recognition and rewarding system.

For that it would be necessary to seek for other ways of rewarding the CCQ groups both in financial and recognition terms. An external stimulus, in this case it would be financial and an internal one that embodies the moral matters. It is true that the internal stimulus of ideas takes place in the institution, but the matter of distribution and democratization of obtained results still requires a greater attention from the administration. It would be interesting to have greater stimulus to the ideas without making the projects unviable only for the monetary aspect because it was observed that this ends up discouraging people. On the other hand, it is also necessary to think over the evaluation matter and the rewarding system because it is understood that people do not feel properly awarded when they are awarded a business trip in which the focus is to bring improvements introduced in other companies to the Ambev reality. In a certain way, these rewards could also be done monthly in terms of indirect benefits just as benefits to the worker's family, stimulus and support to individual projects. 
The improvement of the CCQ program would be important to the company, in the sense of expanding the space of generating ideas and creativity expressions, as a convergence of opinions was observed regarding the concept of creativity being strongly associated to the making something new and seek improvements. This is one of the objectives of the CCQ, besides constituting an instrument of solving problems and improving the working environment.

\section{Results OF CREATIVITy Evaluation IN TEAMWORK}

Specifically concerning teamwork, some of the characteristics are confirmed in the group under study, which lead to approximating to what is called teamwork by Mucchielli (1980). Among them there is a small number of people with an interpersonal link and awareness of common objectives; organizing roles and distribution of work; personal engagement and complementary actions around the objectives; and the presence of private social units, as each one of the groups presents peculiarities which differentiate them from the others.

Those characteristics can be observed in the interviewees' rhetoric, especially when the People and Quality manager believes 'everybody has to be a family and know which is degree of your contribution to the group'. In the opinion of an interviewed operator, 'work in a team all the members having the same vision and trying to speak the same language so that together they achieve the objectives that later will bring professional growth, better finances and social well-being'.

One of the interviewees says when 'I work in teamwork it means single objective. It seems to be work similar to a team because one depends on the work of the other to reach the objectives of the group'. Reinforcing that interpretation, one operator emphasizes that 'working in team means all the members work together in order to reach a goal'. In this same sense, another interviewee adds that 'working in a team there are people that act in harmony in a certain area in search of a common result'.

In some cases, the CCQ's are closer to the concept of a team, mainly when it becomes evident that in these groups there are more multidisciplinary and a collective intention driven to the objective accepted and wanted by all the members of the group. An operator interviewee tells, 'the great advantage when we began with the CCQ it was that kind of group could be multifunctional'. Another interviewee believes that 'the intention of CCQ is to join people of different areas, because a person outside of the area sees what I am not observing because of the work routine'.

In view of the objectives, in the CCQ's their own members establish them. The people's identity with the objectives and the cooperation among them seeking the common purpose makes the concept of this type of group approach the team concept. According to an interviewee, in the CCQ people 'will work on improvements, it can be an improvement in any one of the areas, but people will specifically work on improvements'. In another interviewee's opinion, 'in the CCQ people can develop a lot of creativity. This fact motivates the search for alternatives for the employees' well-being'. For an analyst in the People and Quality area, 'in CCQ we won't look at the part of the profit, but of the employee to feel well inside the company. Besides that we think how should we create an atmosphere of pleasant work and improve the quality of the employees' life'.

On the other hand, the discipline to refuse freedom and accept the common tactics to reach the objectives, i. e., not playing the personal game and working in team seems to be more emphasized in the CGA's due to the demand for reaching the corporative aims. As highlighted by one of the employees, 'the work in a team would be the group of CGA in that people work to reach goals'. In the same train of thought, an operator highlights that the 'work in a team is a cell of its own. The cell is a team where you work together for your own business'. In the opinion of the People and Quality manager, 'the strategy of the circles is in reality the search of the units to be internally competitive and to give that contribution for the competitiveness of the company. In reality a differentiation is seen to be more efficient and productive'. 
The results indicate the meaning of teamwork in the institution studied is strongly associated with an objective that is the emphasis on teamwork is a guided task. That characteristic is evident in an interviewee's report that highlights that 'in the CGA the main difference is that you create owner for each activity and it doesn't have a hierarchy among the owners'. Another interviewee emphasizes that in the CGA 'the negative side is that people are overloaded with work. The people are so busy that they can't cope with all the work to do. We work in shifts and in some weeks it happens that people don't have a day off, because on it we have to work to solve the problems of work for the group'.

Maximiano (1986) and Mucchielli (1980) emphasize that this orientation is characterized by the strong emphasis on results. In addition, teamwork is helping and collaborating with your workmates, but it also means one depending on the others to reach the determined productive aims. On the other hand, it was observed that the workers also understand that working in groups is a chance to exchange information and an opportunity to create new ideas and improved practices. For a planning analyst the work in team 'it is an exchange of experience, because in a team you will always be learning'. For an employee of the stock area, teamwork 'means to divide responsibilities and to find solutions for problems'.

In relation to the objectives, it was seen that, at least apparently, the CCQ's have greater autonomy to define their objectives than the CGA's. However, this autonomy is limited by financial conditions, because the projects undergo rigorous evaluation of benefit-cost. Even though there are relative limitations to financial conditions it was possible to verify that the CCQ is considered one of the more appropriate spaces for proposing ideas and developing creativity because there is great openness and freedom in these groups. According one of the interviewees 'inside the CCQ group the space to expose ideas and to develop my creativity potential is $100 \%$ '. For another interviewee, 'the CCQ is the best space to expose your ideas. The work in the CCQ consists of bringing ideas that involve some benefits for all the employees in the factory'. The BIS - Idea and Solution Bank - a new version of the suggestion box; was also seen as an instrument for proposing and sharing new ideas. An interviewee observes that in the CCQ's people have 'several creative ideas for improvements. The company makes the best practices annually and we have the idea and solution bank (BIS), where we have several creative projects from other units where people can consult some improvement ideas to apply in their own work reality’.

Concerning the people creativity expression study in the context of the institution, it was registered that the company works with the psychological approach aspects of creativity, mainly in the resolution of problems. Besides that, the presence of external stimulus (financial) to motivate the individuals for creativity and innovation was seen. However, an operator interviewee observes that the company stimulates people's creativity 'to increase production and to reduce costs. They motivate you to be more creative and have new ideas to facilitate the processes of the company. In the CCQ there is a reward for the best ideas, but that reward is a trip to visit another company and you come back you have to prepare a report and to provide explanations for a lot of people'. The sociological approach is also present; specifically because of the way found in the company to facilitate the development of people's creativity expression is organized teamwork. In the vision of the Manager of the Ambev S.C. branch, when a company 'begins to give openness and freedom to people's creativity, the result is fantastic. Then when we speak in a workgroup, we can never think about hindering people's creativity'.

Nevertheless, as was pointed out during the work, the company works with logic marked by instrumental rationality. In this way, it was evident that the instrumental approach is the one which best characterizes and explains the stimulus for people's creativity expression in the company. In this work, the concept of autonomy is related to the creation question, because 'it is a question of establishing new ways of working, of recreating the use of space and time, of creating a new technology which allows work to become not one more condemnation but a source of creativity" (Bruno, 1990, p. 82). Being specific about people creativity expression in the researched groups ambit, it was verified that in the CGA's there are limitations to people's creativity expression. According to those interviewed, the main obstacles to people's creativity expression in the company are the cost- 
benefit of projects, the lack of financial incentives, the lack of time and heavy work load, the accumulation of activities and the excessiveness of recording.

For one of the interviewees, one of the largest blocks to the generation of ideas is 'when you have a great idea and the management agrees that it is a good idea, but at the moment of the investment they cut the resources because of costs'. For another interviewee, the largest blockade 'is the rush of daily life, because our work routine is very demanding. People have ideas that could be valuable, but they get lost because of the excess of work and the accumulation of activities'.

The great interest of the institution is the reduction of costs and the increase of profits for the company. The value attributed to creativity expression and workers' ideas is acknowledged through the propagation of work events, professional growth opportunities and rewards. On the other hand, the main benefits obtained by the company with the people's creativity is the cost reduction, better economic results and higher gains, and the improvement of quality in the production process. To the employees, creativity leads to employment and higher levels of job stability, higher motivation to work, a more pleasant work environment and better quality of life.

\section{FINAL CONSIDERATIONS}

According to the results obtained, among the characteristics of the institution is the search for aims, goals and results. The company clearly works according to an instrumental rationality, because all actions are calculated with the corporative aims in mind. Challenge is also one very evident characteristic. However in many interviews, the dissatisfaction of workers is seen concerning the workload as many understand that the work in the institution has used up their lives.

Concerning the imposition of challenges and the pressure for results, it is perceived that these have a negative influence on people's creative potential, because the burden of work and excessive demand for results only work as an external way of motivation to creativity confirming the ideas presented by Amabile (1998).

Another characteristic of the institution is its informality. This is considered to work as an important factor in the generating of ideas, because there is relative freedom for the exchange of information. It was observed that informality also facilitates dialog and help people find solutions to problems in groups. The awarding systems are mainly marked by economical rewards.

Due to this, a need was observed among employees for greater recognition of their work and support for individual projects. Generally a big company offers many benefits, shares and bonuses, proportional to estimated gains. However, a great part of the workers' income depends on these bonuses, which constitutes, a very efficient strategy of the company to motivate cooperative attitudes that rewards the company. In practical terms the high benefits cannot be transferred to other jobs, that is why, the economic rewards end up generating a high level of dependency of the employee on the company. Consequently, in agreement with Hirata (1993), it is normal to observe many workers staying in the company after hours, doing overtime, cutting their vacation, the high participation and involvement in the suggestion plans and quality circles as a way of the employees showing their integration in the company.

In reference to the CGA's it was seen that the aims and objectives are top-down, reinforcing the fact of relative autonomy in this type of group. The emphasis is concentrated on autonomy to improve the efficiency of machines and processes (quality and productiveness). Thus, autonomy in relation to the determination of objectives and aims is limited due to corporative aims (guidance). Based on Salerno (1999) it is believed that, contrary to using the denomination self-management cell, it is preferable to call these groups semi-autonomous, bearing in mind the business context there is hardly a totally autonomous group, because it is immersed in a bigger institution which impose determined guidance, objectives, aim, restrictions and limits. 
According to Guimarães (1995), it is believed that these groups aim at more efficient control of the process and workers, and they cannot be considered as a way of democratizing and sharing the power in the company. In this way, it is registered that the CGA's do not break up totally with the classical administration principles, mainly because it is evidently the resistance in the company to the workers to participate in the definitions of business strategies, in this way keeping the Taylor separation between conception and execution of work (Leite, 1994).

Concerning the generation of ideas, the concept of autonomy and creativity is considered inseparable. In this way, considering the presenter characteristics, it is important to say that the CGA's are considered to partially correspond to the aspects mentioned in literature in order to be considered completely autonomous. As mentioned above, even though it represents an evolution in relation to the traditional model adapted in many institutions, the autonomy attributed to the CGA's do not totally correspond to the concept of autonomy presented in this work.

Considering to the CCQ's, it was possible to verify that the coordination has been experiencing difficulties, mainly in terms of the consistency of the program. It was noted that there is a certain weakening regarding the involvement of workers with the CCQ's, mainly in virtue of the burden of work and extremely challenging goals imposed to the workers in the CGA's. Because of this, many workers are priorizing the aims of the CGA and leaving the CCQ only as a support or in second place.

To better understand this fact it is interesting to reconsider the ideas of Leite (1994), in which there is the explanation to the little interest on the part of workers in the CCQ's. In many cases, these groups are limited to local versions of new models of organizing the work and the creation of participative schemes to integrate the worker in the company, without having substantial changes in the relations of power. In this way, the resistance to the CCQ's ended up emptying many of the initiatives and making the workers drives their attention to the other techniques.

Besides that, the business rhetorician tries to mask the unifying character of participative programs asserting to be volunteer. In this case there are evidences that the adhesion to the company programs cannot be automatically interpreted as ideological integration, because participating is not optional, but lack of option. As highlighted by Shiroma (1996) his researches the workers cannot be blamed for being "committed to the company", when another alternative is to become a "jobless".

In short, it is seen, even though the CGA's and CCQ's establish new working relations in the institutions, these groups do not constitute a rupture in the classical administration approach principles and in traditional patterns of administration found in literature. Its is believed that they only represent a company's strategy to obtain better results and search for consensus and conflict amortization as found in the studies accomplished by Guimarães (1995), Marx (1992) and Salerno (1992). In this away, it is evident that the teamwork and the participative schemes seen as industrial democracy show ideological eminent objective and have constituted the common sense of management rhetoric.

Consequently, the important aspect of the development of new organizational forms of production and work are emphasized that appear in a democratic environment. Furthermore, it is believed that it is important to amplify the space of valorization of the human being creative potential and his / her creative expressiveness, not only as an instrumental practice to improve the productiveness-quality, but also as a space of seeing the working environment as a place of reality transformation.

\section{REFERENCES}

Alencar, E. L. S. de. (1995, novembro/dezembro). Desenvolvendo a criatividade nas organizações: o desafio da inovação. Revista de Administração de Empresas, 35(6), 60-11.

Amabile, T. M. (1998, September/October). How to kill creativity. Harvard Business Review, 76(5), 77-87. 
Amabile, T. M. (1990). From individual creativity to organizational innovation. In K. Gronhaug \& G. Kaufmann (Eds.). Innovation: a cross disciplinary perspective (pp. 139-166). Oslo: Norwegian University Press.

Argyris, C. (1992). Enfrentando defesas empresariais: facilitando o aprendizado organizacional. Rio de Janeiro: Campus.

Bruno, L. (1990). O que é autonomia operária. São Paulo: Brasiliense.

Bruyne, P. (1977). Dinâmica da pesquisa em ciências sociais: os pólos da prática metodológica. Rio de Janeiro: F. Alves.

Companhia de Bebidas das Américas - AmBev (2001a) Círculos de gestão autônoma. Filial Santa Catarina. Retreived April 18, 2001, from http://www.ambev.com.br/emp_03b.htm

Companhia de Bebidas das Américas - AmBev (2001b). Círculos de controle da qualidade. Filial Santa Catarina. Retreived April 18, 2001, from http://www.ambev.com.br/emp_03b.htm

De Bono, E. (1994). Criatividade levada a sério: como gerar idéias produtivas através do pensamento lateral. São Paulo: Pioneira.

Galbraith, J., \& Lawler, E. E. III. (1995). Desafios à ordem estabelecida. In J. Galbraith \& E. E. Lawler III (Eds.). Organizando para competir no futuro (pp. xix-xxviii). Rio de Janeiro: Makron Books.

Garcia, R. M. (1980, julho/setembro). Abordagem sócio-técnica: uma rápida avaliação. Revista de Administração de Empresas, 20(3), 71-77.

Goleman, D., Kaufman, P., \& Ray, M. (1992). O espírito criativo. São Paulo: Cultrix.

Guimarães, V. N. (1995). Novas tecnologias de produção de base microeletrônica e democracia industrial: estudo comparativo de casos na indústria mecânica de Santa Catarina. Unpublished Doctoral Dissertation, Universidade Federal de Santa Catarina, Florianópolis, SC, Brasil.

Guimarães, V. N. (1994). Tecnologia e democracia industrial: uma análise das abordagens teóricas referenciais. Anais do Encontro Nacional dos Programas de Pós-Graduação em Administração, Curitiba, PR, Brasil, 18.

Hirata, H. (1993). Sobre o modelo japonês. São Paulo: EDUSP.

Isaksen, S. G. (1990). Educational implications of creativity research: an updated rationale for creative learning. In K. Gronhaug \& G. Kaufmann (Eds.). Innovation: a cross disciplinary perspective (pp. 167-203). Oslo: Norwegian University Press.

King, N., \& Anderson, N. (1990). Innovation in working groups. In M. A. West \& J. L. Farr (Eds.). Innovation and creativity at work (pp. 81-100). New York: John Wiley and Sons.

Leite, M. P. de (1994). Reestruturação produtiva, novas tecnologias e novas formas de gestão da mãode-obra. In C. A. Oliveira, de, J. E. Mattoso, J. F.Siqueira Neto, M. Pochmann, \& M. A. Oliveira, de (Eds.). O mundo do trabalho: crise e mudança no final do século (pp. 563-587). São Paulo: Página Aberta.

May, R. (1975). A coragem de criar. Rio de Janeiro: Nova Fronteira.

Marx, R. (1992, abril/junho). Processo de trabalho e grupos semi-autônomos: a evolução da experiência sueca de Kalmar aos anos 90. Revista de Administração de Empresas, 32(2), 36-43.

Maximiano, A. C. A. (1986). Gerencia de trabalho de equipe. São Paulo: Pioneira.

Michelat, G. (1987). Sobre a utilização da entrevista não-diretiva. In M. Thiollent (Ed.). Crítica metodológica, investigação social e enquete operária (pp. 191-212). São Paulo: Polis. 
Muchielli, R. (1980). O trabalho em equipe. São Paulo: Martins Fontes.

Nakajima, S. (1989). Introdução ao TPM - total productive maintenance. São Paulo: IMC Internacional Sistemas Educativos.

Neves, M. A. de (1998). Reestruturação produtiva e estratégias no mundo do trabalho: as conseqüências para os trabalhadores. In A. M. C. Neto de \& R. A. A. Carvalho de (Eds.). Sindicalismo e negociação coletiva nos anos 90 (pp. 329-338). Belo Horizonte: Instituto de Relações de Trabalho da Pontifícia Universidade Católica de Minas Gerais.

Richardson, R. J. (1999). Pesquisa social: métodos e técnicas. São Paulo: Atlas.

Ruas, R., \& Antunes, E. (1997, janeiro/março). Gestão do trabalho, qualidade total e comprometimento no cenário da reestruturação. São Paulo em Perspectiva, 11(1), 42-53.

Ruas, R., Antunes, J. A., \& Roese, M. (1993). Avanços e impasses do modelo japonês no Brasil: observações acerca de casos empíricos. In H. S. Hirata (Org.). Sobre o "modelo" japonês: automatização, novas formas de organização e de relações de trabalho. São Paulo: Editora da Universidade de São Paulo.

Salerno, M. S. (1999). Projeto de organizações integradas e flexíveis: processos, grupos e gestão democrática via espaços de comunicação-negociação. São Paulo: Atlas.

Salerno, M. S. (1992, julho/setembro). Reestruturação industrial e novos padrões de produção: tecnologia, organização e trabalho, São Paulo em Perspectiva, 6(3), 100-108.

Shiroma, E. O. (1996). A formação do trabalhador disciplinado. In F. S. Fidalgo (Ed.). Gestão do Trabalho e Formação do Trabalhador (pp. 39-46). Belo Horizonte: Movimento de Cultura Marxista.

Triviños, A. N. S. (1987). Introdução à pesquisa em ciências sociais: a pesquisa qualitativa em educação. São Paulo: Atlas.

Vergara, S. C. (1997). Projetos e relatórios de pesquisa em administração. São Paulo: Atlas.

West, M. A., \& Farr, J. L. (1990). Innovation at work. In M. A. West \& J. L. Farr (Eds.). Innovation and creativity at work (pp. 03-13). New York: John Wiley and Sons. 